IJAMSR 3 (5) www.ijamsr.com CrossRef: https://doi.org/10.31426/ijamsr.2020.3.5.3313

\title{
Security as the Enemy of Digital Transformation
}

\section{Shabnam Arora}

Assistant Professor, Smt. AAA Govt. PG College Kalka, Haryana, India

Email: shabnam.kwatra@gmail.com

Keywords:

\section{Security,}

Digital Media,

Cyber,

Search Engine

\section{A B S T RA C T}

Digital marketing required an investment of time and also effort. To make the digital marketing success, various things have to be done such as conducting marketing research, identifying the target audience, etc. A good strategy is required for the success of digital marketing. In this paper we review how to reach the success strategy of Digital Marketing through Cyber Security Challenges.

Digital transformation is about change, agility, speed, connectivity, real-time economy, customer expectations, and disruption. Security in the eyes of many stands in the way of all this. More than 3 in 4 (76 percent) of respondents believe security is brought in too late to digital transformation initiatives. It's about rules and regulations, protection, defense (even if in reality cyber security becomes pro-active and offense), training, awareness, boring stuff.

Citation: Shabnam Arora (2020). Security as the Enemy of Digital Transformation. International Journal of Advanced Multidisciplinary Scientific Research (IJAMSR) ISSN:2581-4281, 3 (5), May 2020, Pp 23 - 31 
IJAMSR 3 (5) www.ijamsr.com CrossRef: https://doi.org/10.31426/ijamsr.2020.3.5.3313

\section{J A M S R}

\section{International Journal of \\ Advanced Multidisciplinary Scientific Research (IJAMSR) ISSN:2581-4281}

\section{Introduction}

Digital marketing is one type of marketing being widely used to promote products or services and to reach consumers using digital channels. Digital marketing extends beyond internet marketing including channels that do not require the use of Internet. It includes mobile phones (both SMS and MMS), social media marketing, display advertising, search engine marketing and many other forms of digital media. Through digital media, consumers can access information any time and any place where they want. With the presence of digital media, consumers do not just rely on what the company says about their brand but also they can follow what the media, friends, associations, peers, etc., are saying as well. Digital marketing is a broad term that refers to various promotional techniques deployed to reach customers via digital technologies. Digital marketing embodies an extensive selection of service, product and brand marketing tactics which mainly use Internet as a core promotional medium in addition to mobile and traditional TV and radio.

\section{Various Elements of Digital Marketing}

There are various elements by which digital marketing is formed. All forms operate through electronic devices. The most important elements of digital marketing are given below:

\section{(i) Online Advertising}

Online advertising is a very important part of digital marketing. It is also called internet advertising through which company can deliver the message about the products or services. Internet-based advertising provides the content and ads that best matches to consumer interests. Publishers put about their products or services on their websites so that consumers or users get free information. Advertisers should place more effective and relevant ads online. Through online advertising, company well controls its budget and it has full control on time.

\section{(ii) Email Marketing}

When message about the products or services is sent through email to the existing or potential consumer, it is defined as email marketing. Direct digital marketing is used to 
IJAMSR 3 (5) www.ijamsr.com CrossRef: https://doi.org/10.31426/ijamsr.2020.3.5.3313

\section{J A M S R}

\section{International Journal of \\ Advanced Multidisciplinary Scientific Research (IJAMSR) ISSN:2581-4281}

send ads, to build brand and customer loyalty, to build customer trust and to make brand awareness. Company can promote its products and services by using this element of digital marketing easily. It is relatively low cost comparing to advertising or other forms of media exposure. Company can bring complete attention of the customer by creating attractive mix of graphics, text and links on the products and services.

\section{(iii) Social Media}

Today, social media marketing is one of the most important digital marketing channels. It is a computer-based tool that allows people to create, exchange ideas, information and pictures about the company's product or services. According to Nielsen, internet users continue to spend more time with social media sites than any other type. Social media marketing networks include Facebook, Twitter, LinkedIn and Google+. Through Facebook, company can promote events concerning product and services, run promotions that comply with the Facebook guidelines and explore new opportunities. Through Twitter, company can increase the awareness and visibility of their brand. It is the best tool for the promotion of company's products and services. In LinkedIn, professionals write their profile and share information with others. Company can develop their profile in LinkedIn so that the professionals can view and can get more information about the company's product and services. Google+ is also social media network that is more effective than other social media like Facebook, Twitter. It is not only simple social media network but also it is an authorship tool that links web-content directly with its owner

\section{(iv)Text Messaging}

It is a way to send information about the products and services from cellular and smart phone devices. By using phone devices, company can send information in the form of text (SMS), pictures, video or audio (MMS). Marketing through cell phone SMS (Short Message Service) became increasingly popular in the early 2000s in Europe and some parts of Asia. One can send order confirmations, shipping alerts using text message. Using SMS for campaigns get faster and more substantial results. Under this technique, companies can send marketing messages to their customers in real-time, any time and can be confident that 
IJAMSR 3 (5) www.ijamsr.com CrossRef: https://doi.org/10.31426/ijamsr.2020.3.5.3313

\section{J A M S R}

\section{International Journal of \\ Advanced Multidisciplinary Scientific Research (IJAMSR) ISSN:2581-4281}

the message will be seen. Company can create a questionnaire and obtain valuable customer feedback essential to develop their products or services in future.

\section{(v) Affiliate Marketing}

Affiliate marketing is a type of performancebased marketing. In this type of marketing, a company rewards affiliates for each visitor or customer they bring by marketing efforts they create on behalf of company. Industry has four core players: the merchant (also known as "retailer" or "brand"), the network, the publisher (also known as "the affiliate") and the customer. The market has grown in such complexity resulting in the emergence of a secondary tier of players including affiliate management agencies, super-affiliates and specialized third party vendors. There are two ways to approach affiliate marketing: Company can offer an affiliate program to others or it can sign up to be another business's affiliate. If company wants to drive an affiliate program, then, the company owner has to pay affiliates a commission fee for every lead or sale they drive to company's website. So, introducing one's offer through "trusted" company can grab the attention of prospects which might not have otherwise reached.

\section{(vi) Search Engine Optimization (SEO)}

Search engine optimization (SEO) is the process of affecting the visibility of a website or a web page in a search engine's "natural" or un-paid ("organic") search results. In general, the earlier (or higher ranked on the search results page), and more frequently a website appears in the search result list, the more visitors it will receive from the search engine users. SEO may target different kinds of search including image search, local search, video search, academic search, news search and industry-specific vertical search engines.

\section{(vii) Pay Per Click (PPC)}

Pay-per-click marketing is a way of using search engine advertising to generate clicks to your website rather than "earning" those clicks organically. Pay per click is good for searchers and advertisers. It is the best way for company's ads since it brings low cost and greater engagement with the products and services. 
IJAMSR 3 (5) www.ijamsr.com CrossRef: https://doi.org/10.31426/ijamsr.2020.3.5.3313

I J A M S R

\section{International Journal of \\ Advanced Multidisciplinary Scientific Research (IJAMSR) ISSN:2581-4281}

\section{Challenges in Digital Marketing}

(i) Client Winning and Client

Retention

Many businessmen start an agency with one or two clients in hand but later get stuck when they are not in a position to win new clients. Winning a client is one of the biggest challenges when there is a lot of competition especially in the markets like Mumbai, Bangalore and Delhi, there are agencies in every area, unlike Chennai and Hyderabad. Many startup agencies don't know how to win a client but yet start their journey with some years of experience. Client retention is yet another problem in the Industry, clients are not educated enough, on one side they are okay to spend thousands of rupees in traditional campaigns without any distinct ROI and on the contrary, they don't see great value in Digital. Most of the clients try to stick on to an agency on an average 3 years and then they think of moving away from them, there could be a lot of reasons for this:

a) Ask for hike and face the consequences When a small agency asks for a hike in their monthly retainer, clients usually threaten them with an exit statement, saying we will have to move out and find an alternative agency. This puts a lot of pressure on agency owners, while the team handling the accounts their salaries have grown but the retainers of the client haven't, leaving a very poor profit margin.Yet, the agency owners don't say goodbye to these clients as they fear this would impact their cash flow and somehow they satisfy themselves saying, it's one of our oldest clients and we would like to keep the relationship maintained.

b) New marketing head Doesn't like you at all Clients generally move out for fresh ideas. Also, when there is a change of Marketing head or manager the agency becomes a cat on the wall perplexed between pleasing the new manager and maintaining the deliverables whereas, the new manager always aims to bring the agency that they are most comfortable with, ending up finding loopholes in the services delivered. It becomes a dirty affair.

(ii) The Changing Landscape of Digital:

Half of the agency gets washed because they are not able to cope up with the rapidly changing digital landscape. Facebook's reach was organic, agencies offered a lot of posts then, 3 posts per day and those sorts. The 
IJAMSR 3 (5) www.ijamsr.com CrossRef: https://doi.org/10.31426/ijamsr.2020.3.5.3313

\section{International Journal of Advanced Multidisciplinary Scientific Research (IJAMSR) ISSN:2581-4281}

deliverables looked fascinating, it worked back then and there are still agencies sticking on to same old thing whereas, the industry doesn't want many posts anymore. It's about minimalistic stuff which agency owners fail to understand. The changing landscape of digital demands for strategy first and creativity 2nd but the advertising agencies that got turned into digital agencies puts creativity first, failing to work towards strategy a strategy that defines ROI of the effort put in. The Digital landscape changes overnight and the client in India needs to be educated about it, half of them don't understand the value of advertisements on Social Media or digital. They would give you a fixed retainer and wait for magic to happen, they should learn agencies are not magicians to get you likes, comments and shares for Free. This makes the agency gets into foul practices.

\section{(iii) Client Payments:}

The biggest mistake agency owners do: they don't sign a contract with the client before they start offering their services and don't ask for payments on time. An ideal agency would raise the bill on time, and demand payments on time and also stop offering the services if the payments are not made. Client payments is the fuel for the agency's happiness, don't compromise on this. Learn about payment history of clients from other vendors who they have worked it. A poor paying client slowly becomes blacklisted in the city and no one would like to work with them.

\section{(iv) Usage of Cards}

This is again one of the biggest challenges. For facebook advertisements we generally convince client to use their cards, as there is a lot more transparency.

\section{(v) Lack of Talent:}

Digital Marketing is accidental for many, it's not by choice. When it's not by choice, the candidates don't pour their heart in. Most of the SEO guys in Chennai city are still following what they learnt in 2011 - directory submissions whereas Google wants great content in first place. Talent is the biggest problem in the digital marketing industry, most of them are freshers and you will have to mould them to become a good digital marketer. Whereas, the experienced ones generally don't like to hang out in agencies as they find their solace on the client side. This gap is yet not 
IJAMSR 3 (5) www.ijamsr.com CrossRef: https://doi.org/10.31426/ijamsr.2020.3.5.3313

\section{J A M S R}

\section{International Journal of \\ Advanced Multidisciplinary Scientific Research (IJAMSR) ISSN:2581-4281}

met, and it will take another few years to have good digital marketers in the country.

\section{(vi) Rising Attrition:}

Most of the agencies in India are filled with millennial, and working with a millennial mindset is a challenge in itself. Attrition is one of the key challenges that agency owners are facing, floating employees have become a norm. As the digital crowd starts becoming $30+$, there is going to be a lot more stillness in the floating populace.

\section{Why Cyber Security Maturity And Strategy Are Lagging Behind}

\section{(i) Security Requires Strategy And Prioritization}

Security isn't always easy and does not start by adding security controls but by prioritizing the most critical processes, systems and potential sources of attacks or vulnerabilities. Needless to say that in the realm of the Internet of Things, vulnerability risks increase by the way. So, security needs a strategy and that is harder than adding a few firewalls of course. (ii)

\section{The Business Case Challenge Of Cyber Security}

It's harder to make the business case for security than it is to, for instance, make the case for a digital transformation project in regards with the digital workplace, collaboration or customer experience. You're analyzing risks and dealing with the unpredictable. Rather than looking at the gaining back of costs, it's sometimes better to factor in the losses if you fail to properly secure what needs securing. The problem is that you only truly know it when it happens and your business is interrupted, data stolen, compliance requirements breached or reputation down the drain.

\section{(iii) Specific Security Skill Set Challenges.}

Skills is another one. It's true that for many large organizations it's harder to find the right security experts for specific applications, also in a context of digital transformation where often loads of data are involved and rather new technologies surface. But the shortage is an overall challenge (and there are partners to deal with it). 
IJAMSR 3 (5) www.ijamsr.com CrossRef: https://doi.org/10.31426/ijamsr.2020.3.5.3313

(iv) Security On The Level Of The User In A Mobile Age

The security parameter has changed. The cyber security perimeter is a but everywhere, the attack surface has grown and good old point solutions or firewalls alone don't cut it anymore and in a digital transformation context protection at the level of the mobile user is a must.

\section{(v). The Critical - But Undervalued - Role} Of Data And Information In Transformation.

The role of information and data, critical in digital transformation, is still all too often undervalued. Data and information are the lifeblood of the business and a source of revenues and new business models. In fact, the DX economy essentially is very much about 3 things: people, purpose and actionable information, regardless of the source. Unfortunately, this isn't reflected enough in the cyber security maturity levels of many organizations, nor in their compliance and/or governance measures, for that matter. According to the 2016 Ponemon Institute Cost of Cyber Crime Study infographic, information loss accounts for almost 40 percent of the damage of cybercrime and companies with an advanced information governance program reduce losses by $\$ 1$ billion annually.

\section{Conclusion}

If you want digital transformation to succeed, changing the mindset, strategy and maturity regarding security is a must. Involve security from the very beginning, make it embedded, look at data protection and privacy as assets and strengths instead of costs and give the CISO or other security executive a place around the table. In case you doubt: yes, CISOs are also expected to generate new business opportunities. 
International Journal of Advanced Multidisciplinary Scientific Research (IJAMSR) ISSN:2581-4281 Volume 3, Issue 5, May 2020

IJAMSR 3 (5) www.ijamsr.com CrossRef: https://doi.org/10.31426/ijamsr.2020.3.5.3313

I J A M S R

International Journal of

Advanced Multidisciplinary Scientific Research (IJAMSR) ISSN:2581-4281

\section{References}

1) G. T. Waghmare, 2012). E-commerce; A Business Review and Future Prospects in Indian Business. Internet Marketing in India. Indian Streams Research Journal, vol. 2, no. IV, (pp. 1-4.

2) Gangeshwer, D. K.(2013). E-Commerce or Internet Marketing: A Business Review from Indian Context" , International Journal of $\mathrm{u}$ and e- Service, Science and Technology Vol.6, No.6, pp.187-194

3) Giese, J. L. and J. A. Gote,(2000) .Defining Consumer Satisfaction,. Academy of Marketing Science Review [Online]00 (01)
4) Gurau, C. (2008). Integrated online marketing communication: implementation and management, Journal of Communication Management, vol. 12 no. 2, pp. 169-184

5) 'Biggest cybersecurity threats in 2016', CNBC, Dec 2015www.cnbc.com/2015/12/28/biggestcybersecurity-threats-in-2016.html

6) Internet Users by Country 2016, Internet Life Stats, July 2016 www.internetlivestats.com/internet-users-bycountry 